\title{
Three New Species of Ferns (Pteridophyta) from Mesoamerica
}

\author{
Alexander Francisco Rojas-Alvarado \\ Universidad Nacional de Costa Rica, Heredia, Costa Rica \\ Email: alfrojasa@yahoo.com
}

How to cite this paper: Rojas-Alvarado, A.F. (2017) Three New Species of Ferns (Pteridophyta) from Mesoamerica. American Journal of Plant Sciences, 8, 1329-1338.

https://doi.org/10.4236/ajps.2017.86089

Received: April 24, 2017

Accepted: May 22, 2017

Published: May 25, 2017

Copyright $\odot 2017$ by author and Scientific Research Publishing Inc. This work is licensed under the Creative Commons Attribution International License (CC BY 4.0).

http://creativecommons.org/licenses/by/4.0/

\begin{abstract}
In this research three new species of ferns of the Polypodiales Order are described: Ctenitis leonii A. Rojas, Elaphoglossum karinae A. Rojas and Pecluma celaquensis A. Rojas. Ctenitis leonii is characterized by its apical stipe scales marginally erose to ciliate, blade surfaces with two types of hairs present in both surfaces, ones $0.7-1.5 \mathrm{~mm}$ long and not glandular, the others $0.3-0.5$ $\mathrm{mm}$ long and glandular and indusia are absent. Elaphoglossum karinae differs from Elaphoglossum dissitifrons Mickel by shorter rhizome, longer and relatively narrower rhizome scales, they lanceolate to linear-lanceolate and blackish costal scales. Pecluma celaquensis is similar to Polypodium martensii Mett., but differs by its thinner rhizome, smaller rhizome scales and these with a crown of brown cilia at the attaching point, relatively shorter stipe with longer hairs and these commonly no glandular, scaly rachis and it with longer and denser hairs, inframedial sori and glabrous sporangia.
\end{abstract}

\section{Keywords}

Ctenitis, Elaphoglossum, Honduras, New Speciefs, Pecluma, Polypodiales

\section{Introduction}

Although no research has been developed exclusively in Honduras to study the diversity of ferns; there are general studies and other isolated works that contribute to it, including:

Molina [1] published the first document where a detailed list of the vascular flora of Honduras, which also included the club mosses and ferns known at the time.

Moran \& Riba [2] published the first volume of the Mesoamerican Flora, which refers to club mosses and ferns of the region, including Honduras.

Nelson et al. [3] showed to the public a database of ferns from Honduras, prepared by Gerrit Davidse of the Missouri Botanical Garden. 
Nelson et al. [3] published "Hondurensis Plantarum Vascularium Catalagus, Pteridophyta", in which 651 species of ferns and club mosses were included, compared with 339 published by Molina [1]. This represents an increase of $92 \%$ of the known pteridophytes from Honduras.

Hernández \& Nelson [4] mentioned Polypodium ursipes Moritz ex C. Chr., a new record from Honduras.

The first study of vegetation from Celaque was presented by Hazlett [5]. Since then several studies have been conducted listings the flora of the region. Recently Piątek et al. [6] published "Ferns and Lycophytes of Celaque National Park, Honduras" which recorded a total of 59 genera and 166 species. However, Rojas [7], based in the same inventory site, discovered nine species were by first time recorded from Honduras and 35 species for the Celaque Mountains National Park (PNMC).

There is a great need to increase the knowledge of the club mosses and ferns in Honduras. This research in the PNMC was conducted in one of the least explored national parks in the country. Three new species were located here: Ctenitis leonii and Pecluma celaquensis, both endemic to Celaque and Elaphoglossum karinae, more broadly distributed in Mesoamerica.

\section{Materials and Methods}

The research was conducted at the Celaque Mountain National Park (PNMC) in Honduras and involved collecting specimens and revision of material at these herbaria: Universidad Nacional Autónoma de Honduras, Cyril Nelson Herbarium (TEFH) and Missouri Botanical Garden (MO). Fieldwork was conducted between the 25 and 30 of June 2012 and consisted of the travel paths of the main street, between the entrance to the park near the community of Villa Verde (1300 $\mathrm{m}$ over sea level) and the park visitor's center $(1400 \mathrm{~m})$, and the path to Heaven between the visitor's center and to the camp El Quetzal $(2630 \mathrm{~m})$ through the camp Don Thomas (1940 m), camp El Naranjo (2560 m) and turning off to Cerro Las Minas (2849 m), to complete an approximate distance of 12 $\mathrm{km}$ and returning. A total of 216 numbers and ferns club mosses representing nearly 170 species were collected.

The specimens were collected and preserved according to the method established by Lorea and Riba [8], and distributed to Museo Nacional de Costa Rica (CR), Escuela Nacional de Ciencias Forestales (HEH) and Universidad Nacional Autónoma de Honduras, Cyril Nelson herbarium (TEFH). Other specimens cited here are deposited in the following herbaria BM, CR, EAP, F, MEXU, MO, NY, TEFH, UC and US (acronyms following Thiers, [9]).

The specimens were mainly revised with the treatments of Ferns and Fern Allies of Guatemala [10], Mesoamerican Flora [2], the Pteridophytes of Mexico [11] and Flora de Nicaragua [12].

To ensure the correct application names, original type material or digital type images were examined as available (Jstor Global Plants (http://plants.jstor.org/)), and the new names were corroborated with International Plant Name Index 
(http://www.ipni.org/ipni/plantnamesearchpage.do ).

\section{Results}

\subsection{New Species}

\subsubsection{Ctenitis leonii A. Rojas, sp. nov. (Figure 1)}

TYPE: Honduras. Lempira: Gracias, Celaque Mountains National Park, main path, up tp Río Arcagual and heading to Don Thomas camp, $14^{\circ} 33^{\prime} 32^{\prime \prime N}$, 88 39'47"W, 1450 - 2100 m, 26 June 2012, A. Rojas et al. 9965 (holotype: CR; Isotypes: TEFH, EAP).

Diagnosis. This new species differs from C. subdryopteris (Christ) Lellinger by its apical stipe scales marginally erose to cilate, blade surfaces with two types of hairs present in both surfaces, ones $0.7-1.5 \mathrm{~mm}$ long and no glandular, the others $0.3-0.5 \mathrm{~mm}$ long and glandular, and indusia absent.

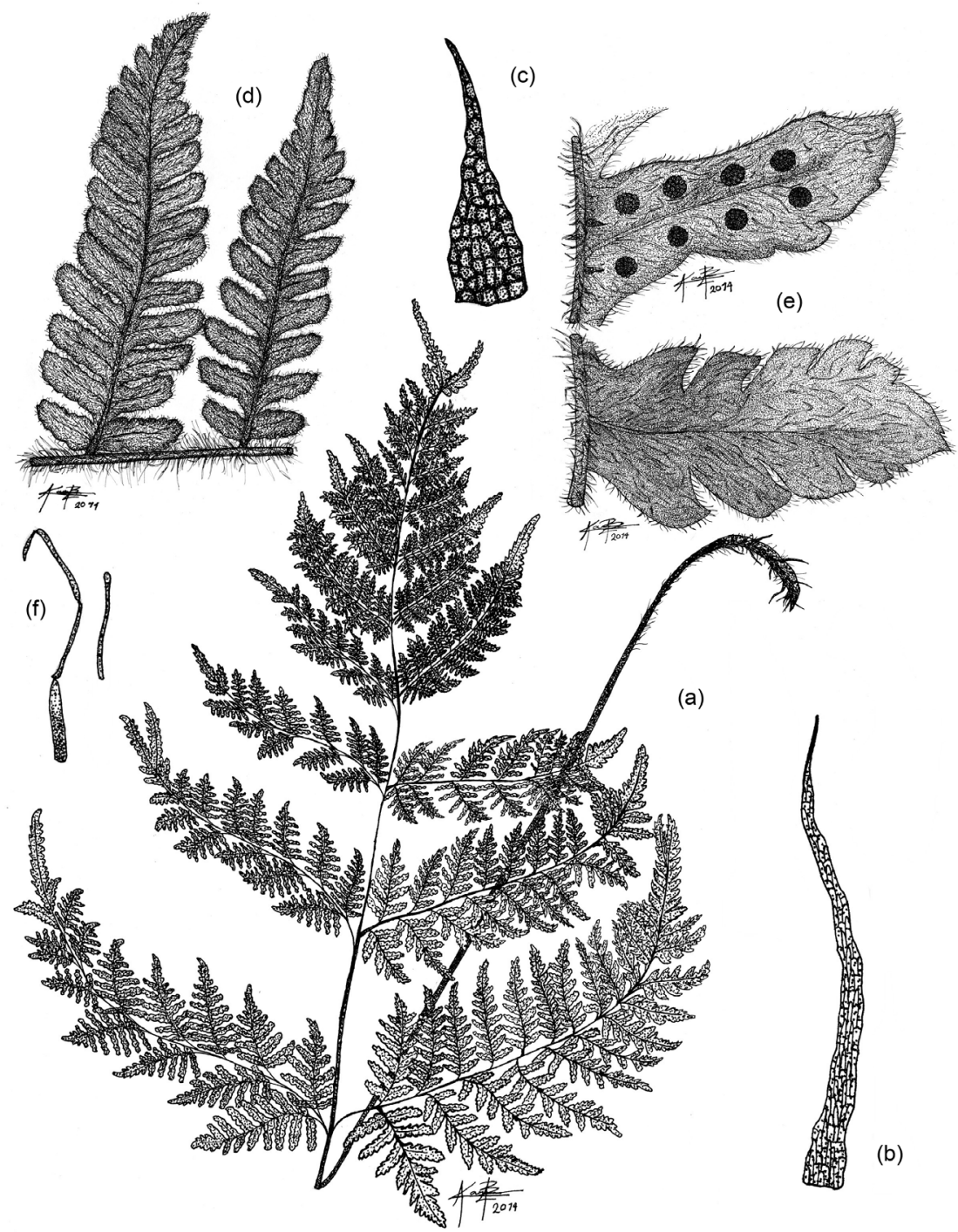

Figure 1. (a)-(f) Ctenitis leonii (A. Rojas et al. 9965, CR): (a) General aspect of type specimen; (b) Rhizome scale; (c) Costal scale; (d) Pinna detail; (e) Segments detail; (f) Abaxial blade hairs. 
Description. Rhizome 5 - $10 \mathrm{~mm}$ in diameter, compact, ascending, scaly, the scales 7 - $10 \times$ ca. $1 \mathrm{~mm}$, linear, brown-gold, entire; fronds $118-140 \mathrm{~cm}$ long; stipe 55 - $65 \mathrm{~cm}$ long, strawish to brown basally, lustrous, very sparsely hairy at full length, densely only at the base, the scales $5-10 \times 0.3-0.7 \mathrm{~mm}$, linear, brown, no clathrate, entire, flaccid; dorsally with scales $0.5-1.5 \times 0.2-0.5 \mathrm{~mm}$, ovate to lanceolate, marginally erose to ciliate; blade $62-75 \times 52-60 \mathrm{~cm}$, ovate, 4-pinnate-pinnatifid at base, 3-pinnate-pinnatifid above the base, basally truncate, apically pinnatifid; rachis, costae and costules straw, sparsely hairy abaxially and densely hairy dorsally, the hairs $0.5-1 \mathrm{~mm}$ long, cateniform, hyaline in the center and brown-yellowish in the cells unions, moderate scaly dorsaly and near the union between rachis, costae and costules, the scales $0.5-2 \times 0.3-0.7 \mathrm{~mm}$, ovate to linear-lanceolate, brown to dark brown, clathrate, appressed, marginally entire to erose; basal and medial pinnae $20-37 \times 8-20 \mathrm{~cm}$, lanceolate; basal pinnae markedly inequilateral, basiscopic pinnules up to double the size of the acroscopic ones, with peduncle $7-10 \mathrm{~cm}$ long; laminar tissue densely hairy in both surfaces, the hairs of the axes and veins $0.5-1.5 \mathrm{~mm}$ long, hyaline to light brown, appressed, cateniform, with brown-yellowish cells unions, the hairs of adaxial surface 0.3 - $1.2 \mathrm{~mm}$ long, appressed, cateniform, with reddish cells unions, the biggest ones with acute apex the smallest with glandular apex, the abaxial hairs similar to adaxial ones, but the hairs on costules and veins $0.7-1.5$ $\mathrm{mm}$ long, and the hairs in laminar tissue commonly $0.2-0.5 \mathrm{~mm}$ long and with glandular apex, but mixed with long non glandular hairs; last segments 2 - $4 \mathrm{~mm}$ de broad, ciliate; veins 1 - 3 pairs per lobule, ending in the margins; sori rounded, medial, without indusia.

Etymology. The new species is dedicated to Misael León Carvajal, ex director of MAPANCE and now director of ICF, for financing the exploration in Parque Nacional Montañas de Celaque through MAPANCE-PROCELAQUE.

Distribution. Known only from Montañas de Celaque in Honduras at 1450 $2100 \mathrm{~m}$.

Observations. Ctenitis leonii differs from $C$. subdryopteris by its apical stipe scales marginally erose to ciliate (vs. entire), blade surfaces with two types of hairs present in both surfaces, ones $0.7-1.5 \mathrm{~mm}$ long and not glandular (vs. this type absent), the glandular ones $0.3-0.5 \mathrm{~mm}$ long (vs. $0.1-0.2 \mathrm{~mm}$ long) and present in both surfaces (vs. present only in abaxial surface), and indusia absent (vs. present) (Figure 1).

\subsubsection{Elaphoglossum karinae A. Rojas, sp. nov. (Figure 2)}

TYPE: Honduras. Lempira: Gracias, Celaque Mountains National Park, main path, between El Naranjo camp and the crossing of the path towards Las Minas

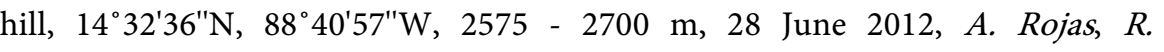
Hernández \& N. Cruz 10066 (holotype: CR; Isotypes: EAP, TEFH).

Diagnoses. Elaphoglossum karinae differs from $E$. dissitifrons Mickel by its shorter rhizome, with longer and relatively narrower scales, these lanceolate to linear-lanceolate and blackish costal scales. 


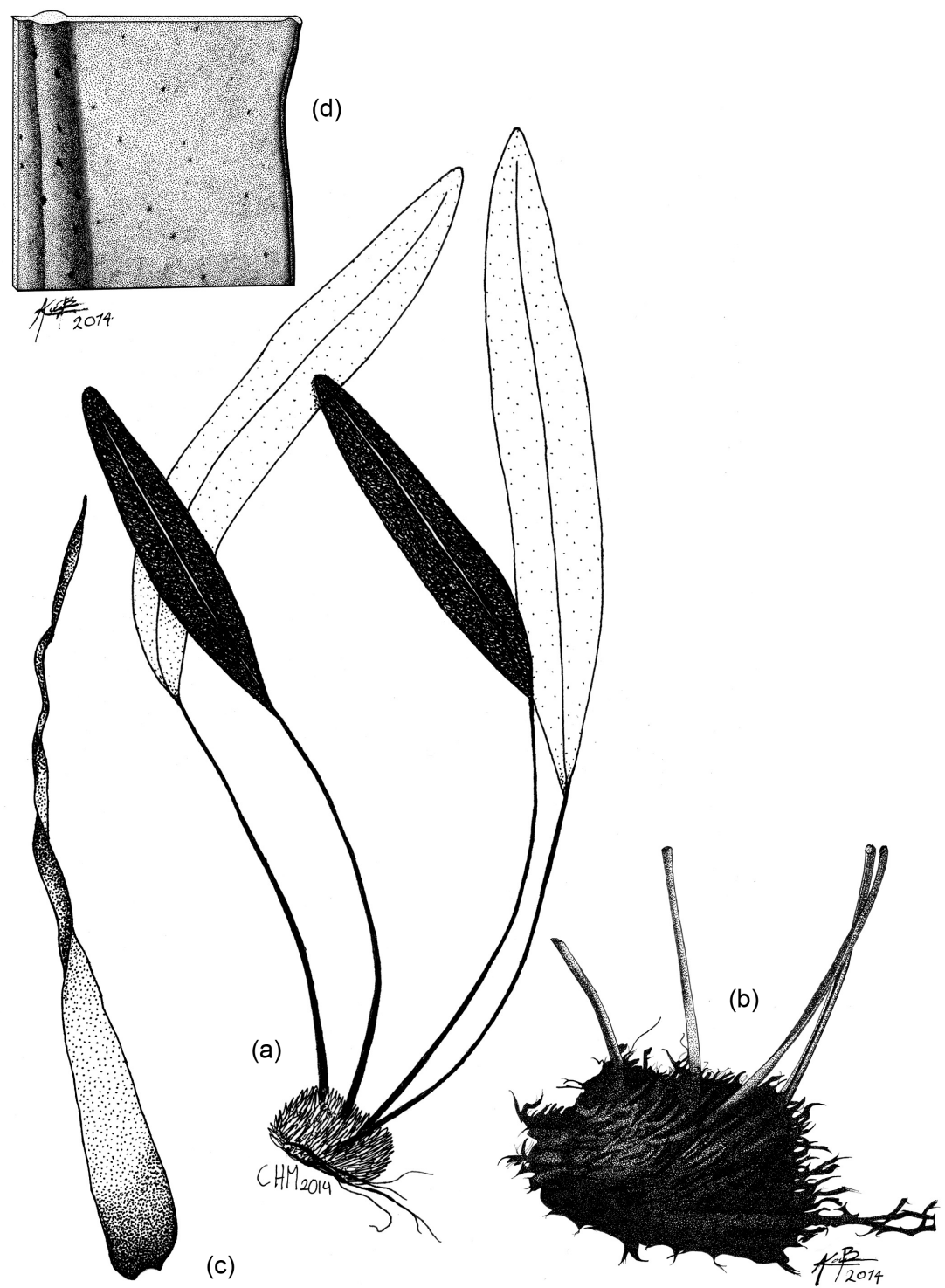

Figure 2. (a)-(d) Elaphoglossum karinae D. Breedlove \& A Smith 31630, MEXU). (a) General aspect of representative specimen; (b) Rhizome; (c) Rhizome scale; (d) blade detail.

Description. Epiphytic; rhizome $2-3 \mathrm{~mm}$ in diameter, creeping, distance between fronds $2-5(-10) \mathrm{mm}$; rhizome scales $5-10 \times 1-2 \mathrm{~mm}$, lanceolate, gold or with brown patches, peltate, flaccid, patent, marginally entire to short-ciliate; fronds 18 - $46 \mathrm{~cm}$ long; phyllopodia 7 - $15 \mathrm{~mm}$ long; stipe 5 - 23.5 $\mathrm{cm}$ long, 1/2 - 1/4 of the frond length, stramineous, scaly at least in the base, the scales $2-5 \times$ ca. $1 \mathrm{~mm}$, the basal ones marginally entire and elsewhere long- ciliate; blade $13-24 \times(2.1-) 2.5-4.3 \mathrm{~cm}$, elliptic, oblong-elliptic or oblanceolate, coriaceous, basally cuneate, apically obtuse to rounded; costa stramineous, scaly or glabrous, the scales $1-2 \times$ ca. $0.5 \mathrm{~mm}$, lanceolate, gold-brown to brown, sparse, marginally with lateral processes; laminar tissue glabrous on both surfaces; veins few evident; fertile fronds 13 - $37 \mathrm{~cm}$ long; stipe (3-) $10-20.5 \mathrm{~cm}$ long; blade $9.5-17 \times 1.6-2.7 \mathrm{~cm}$, elliptic to oblong, basally cuneate, apically 
acute to obtuse; interesporangial scales absent.

Etymology. This species is dedicated to Ruth Karina Hernández Cibrian, pteridologist in Honduras, who collaborated with the Celaque expedition in 2012.

Distribution. Known from Mexico, Guatemala, Honduras and El Salvador at (1400-) 1900 - $3050 \mathrm{~m}$.

Additional revised specimens (paratypes). MEXICO. Chiapas: Mpio. Chamula, NE slope of Zontehuitz near the summit, $9300 \mathrm{ft}$ [=2835 m], D. Breedlove 7812 (F); Mpio. Tenejapa, NE side of the hill called Matsab, Paraje of Matsab, $9200 \mathrm{ft}$ [=2804 m], D. Breedlove 15292 (F); SE side of Volcán Tacaná, above Talquian, 2200 m, 16 Jan 1973, D. Breedlove \& A. Smith 31630 (MEXU); Mpio. Tenejapa, in the Paraje Matsab, $8900 \mathrm{ft}$ [=2713 m], A. Shilom 694 (F). Oaxaca: Teotitlán, 2500 m, C. Conzatti et al. 2137 (MEXU); along road from Teotitlán del Camino to Hautla de Jiménez, 17.8 - 18.3 miles E of Teotitlán, 2300 - 2370 m, T. Croat 48214 (MO, NY, UC); Dist. Ixtlán, Sierra de Juárez, Km 90 of rute 175 Tuxtepeca-Oaxaca, SW of La Esperanza, 2035 m, D. Lorence et al. 3618 (MEXU, MO); Dist. Central, North slope of Cerro San Felipe, 7800 - $8400 \mathrm{ft}$ [=2377 2560 m], J. Mickel \& R. Hellwig 4034 (NY, UC); Dto. Teotitlán, 26 - 29 km NE of Teotitlán del Camino, vicinity of pass of Puerto Soledad, $7000-7400 \mathrm{ft}$ [ $=2134$ - 2256 m], J. Mickel \& R. Hellwig 4152 (NY, UC); Dist. Mixes, SE shoulder of Cerro Zempoaltepetl, $8200 \mathrm{ft}$ [=2500 m], J. Mickel \& S. Leonard 4910 (NY, UC); Dist. Ixtlán, Cerro de Malacate, $\mathrm{N}$ of Capulalpan, ca. $8 \mathrm{~km}$ E of Ixtlán from 7600 - $10000 \mathrm{ft}$ [=2316 - $3048 \mathrm{~m}$ ] on NE side of Cerro, $8850 \mathrm{ft}$ [=2697 m], J. Mickel \& S. Leonard 5246 (NY, UC), J. Mickel \& S. Leonard 5299 (NY, UC); Dist. Ixtlán, $56 \mathrm{~km}$ N of Ixtlán on Rte. 175, $7100 \mathrm{ft}$ [=2164 m], J. Mickel 5593 (NY, UC); Teotitlan de Flores Magon, Raya San Geronimo, $4 \mathrm{~km}$ SE of Plan de Guadalupe, path to Mazatlán de Flores, $18^{\circ} 10^{\prime} \mathrm{N}, 97^{\circ} 01^{\prime} \mathrm{W}, 2800 \mathrm{~m}, P$. Tenorio \& F. Tenorio 18553 (MEXU).

GUATEMALA. Guatemala: Volcán Pacaya, above Las Calderas, 1800 - 2400 m, P. Standley 58487 (F, US). San Marcos: Volcán Tacaná, along Quebrada Canjulá, between Sibinal and Canjulá, 2200 - 2500 m, J. Steyermark s.n. (US). Zacapa: Sierra de Las Minas, between Loma El Picacho and Cerro de Monos, 2000 - 2600 m, J. Steyermark 42813 (GH).

HONDURAS. Comayagua: San Juanillo, section of the Cordillera de Montecillos Biological Reserve, 9 Dec 1991, T. Hawkins et al. 121 (EAP); Montaña de San Juanillo, Cordillera de Montecillos Biological Reserve, path El Danto to Jesús de Otoro, $14^{\circ} 30^{\prime} \mathrm{N}, 87^{\circ} 53^{\prime} \mathrm{W}, 1900$ m, 1 Mar 1991, P. Hause \& S. Aguilar 846 (EAP, MO, TEFH). El Paraíso: Yuscatán, Cerro Monserrat, 2000 m, A. Díaz 180 (CR, UC); ibídem, Zelaya 129 (CR, MO, UC). La Paz: Maguore, 4 km NW of Guajiquiro, $14^{\circ} 09^{\prime} \mathrm{N}, 87^{\circ} 51^{\prime} \mathrm{W}, 2100 \mathrm{~m}, 24$ May 1993, R. Liesner 26528 (EAP, MO, TEFH, UC). Lempira: Montaña de Celaque, SE portion of the massif, main peak just S of the Río Arágual, on plateau, $14^{\circ} 32^{\prime} 30^{\prime \prime} \mathrm{N}, 88^{\circ} 41^{\prime} 00^{\prime \prime} \mathrm{W}, 2670 \mathrm{~m}$, 2670 m, 29 May 1991, G. Davidse 34878 (EAP, MO); Celaque National Park, along Río Arcágual, between visitor's center and dam (water intake for the town of Gracias), $7.5 \mathrm{~km}$ WSW of Gracias, $14^{\circ} 34^{\prime} \mathrm{N}, 88^{\circ} 39^{\prime} \mathrm{W}, 1400 \mathrm{~m}, 11$ Nov 1991, $R$. 
Moran 5515 (MO, UC); Celaque National Park, along Río Arcágual, upstream from base camp 2, $10.5 \mathrm{~km}$ WSW of the town of Gracias, $14^{\circ} 34^{\prime} 05^{\prime \prime} \mathrm{N}$, $88^{\circ} 41^{\prime} 05^{\prime \prime W}, 2500$ m, 16 Nov 1991, R. Moran 5592 (EAP, MO, TEFH); Gracias, Celaque Mountains National Park, between Don Thomas and El Naranjo camps, $14^{\circ} 33^{\prime} 16^{\prime \prime N}, 88^{\circ} 40^{\prime} 15^{\prime \prime W}, 2100$ - 2575 m, 27 Jun 2012, A. Rojas et al. 9982 (CR, EAP, TEFH). Santa Bárbara: Montaña Santa Bárbara, 2350 m, 7 Apr 1951, $R$. Armour \& A. Chable 6123 (EAP); $7 \mathrm{~km} \mathrm{~N}$ of El Monchito, on the E slopes of Mt. Santa Bárbara, $14^{\circ} 55^{\prime} \mathrm{N}, 88^{\circ} 7^{\prime} \mathrm{W}, 2200-2500$ m, 23 Nov 1991, R. Moran 5704 (EAP, MO, TEFH, UC).

EL SALVADOR. Bosque Montecristo, R. Seiler 657 (NY). Chalatenango: E side near summit of Eses Miles, $14^{\circ} 21^{\prime} \mathrm{N}, 89^{\circ} 09^{\prime} \mathrm{W}, 2500 \mathrm{~m}$, J. Tucker 1071 (NY, UC, US). Santa Ana: Montecristo, $14^{\circ} 25^{\prime} \mathrm{N}, 89^{\circ} 22^{\prime} \mathrm{W}, 2100$ - 2250 m, 27 Jan 1998, G. Davidse et al. 37290 (BM, MO); Montecristo, 2300 m, 23 May 1963, A. Molina \& A. Molina 12659 (EAP).

Observations. Elaphoglossum karinae differs from E. dissitifrons by its shorter [fronds distant (0.2-) $0.5-1.0 \mathrm{~cm}$ vs. $0.8-1.7 \mathrm{~cm}$ ] rhizome, longer [(4-) 7 - $12 \mathrm{~mm}$ long vs. 5 - $7 \mathrm{~mm}$ ] and relatively narrower [1 - $2(-3) \mathrm{mm}$ vs. 1.5 - 3.0 $\mathrm{mm}$ )] rhizome scales, which are lanceolate to linear-lanceolate (vs. ovate to ovate-lanceolate) and blackish (vs. yellowish-brown) costal scales (Figure 2).

\subsubsection{Pecluma celaquensis A. Rojas, sp. nov. (Figure 3)}

Type: Honduras. Lempira: Gracias, Celaque Mountains National Park, main path, between El Naranjo camp and the crossing of the path towards Las Minas hill, 143' $36^{\prime \prime} \mathrm{N}, 88^{\circ} 40^{\prime} 57^{\prime \prime} \mathrm{W}, 2575$ - $2700 \mathrm{~m}, 28$ June 2012, A. Rojas, $R$. Hernández \& M. Stufkens 10060 (Holotype: CR; Isotype: TEFH).

Diagnoses. Pecluma celaquensis A. Rojas differs from Polypodium martensii Mett. by its have thinner rhizome, smaller rhizome scales and these with a crown of brown cilia in the attaching point, relatively shorter stipe, relatively longer stipe hairs and they commonly not glandular, scaly rachis and it with longer and dense hairs, inframedial sori and glabrous sporangia.

Description. Epiphytic, on trunks base of old trees; rhizome 3 - $5 \mathrm{~mm}$ in diameter, creeping; rhizome scales 2 - $3 \times 0.5-1.5 \mathrm{~mm}$, ovate to ovate-lanceolate, peltate, gold with dark brown attached point and with a crown of brown cilia just here, they 0.5 - $2 \mathrm{~mm}$ long, the scale margins erose to short ciliate; fronds 45 $-51.5 \mathrm{~cm}$, nearby to $0.5 \mathrm{~cm}$ distant; stipe $6-7.5 \mathrm{~cm}$ long, $1 / 8-1 / 6$ of the fronds size, brown, moderately lustrous, shortly and densely hairy, the hairs (0.5-) 1 $1.5 \mathrm{~mm}$ long, brown, cateniform, crooked; lamina $39-44 \times 8-13 \mathrm{~cm}$, lanceolate, abruptly reduced at base and gradually reduced to a pinnatifid apex; rachis yellowish to brown, scaly and hairy, the scales (1.5-) $2.5-5 \times(0.1-) 0.3-0.5 \mathrm{~mm}$, sparse, the hairs (0.5-) 1 - $1.5 \mathrm{~mm}$ long, brown, cateniform, dense; pinnae linear-lanceolate to linear-deltate, sessile, broadly attached at base in $0.8-1.2 \mathrm{~cm}$, the basal ones reduced to $0.8 \mathrm{~cm}$ long and separate between them to $0.5 \mathrm{~cm}$, the medial ones enlarged to $6.4 \mathrm{~cm}$, the basal ones sometimes with a acroscopic basal lobule and sometimes slightly decurrent on basicopic side; adaxial blade surface moderately hairy, the hairs 0.5 - $1 \mathrm{~mm}$ long, cateniform, hyaline, abaxial blade 


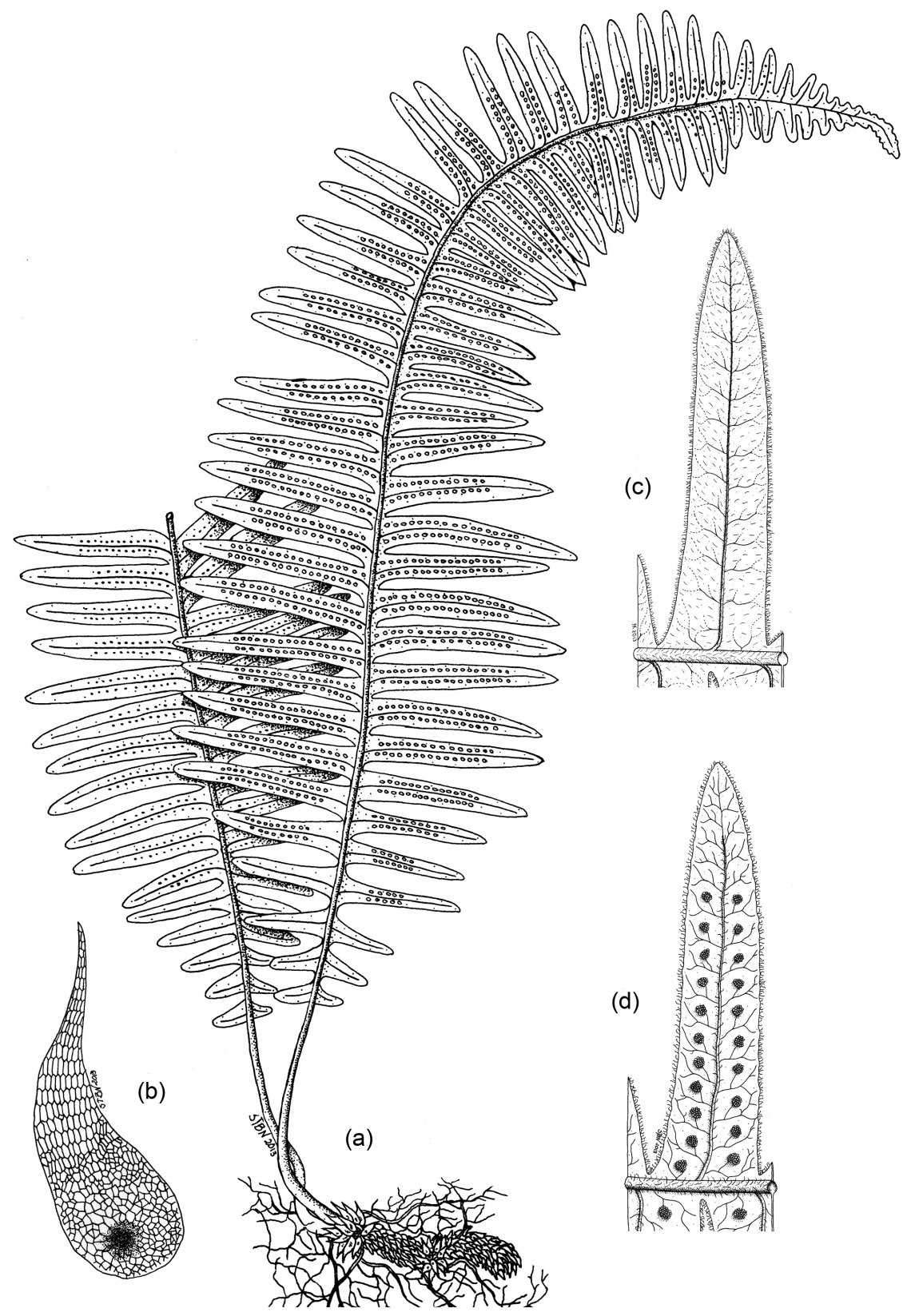

Figure 3. (a)-(d) Pecluma celaquensis (A. Rojas et al. 10060, CR). (a) General aspect of type specimen; (b) Rhizome scale; (c) Adaxial blade detail; (d) Abaxial blade detail.

hairs moderately dense over costae, sparsely hairy over the veins and very rare or absent on the blade surface, the costal hairs $1-1.5 \mathrm{~mm}$ long, the other ones 0.5 $1 \mathrm{~mm}$ long, hairs similar to the adaxial ones, but in costae and veins are pale brown to hyaline with brown walls; blade margin entire to slightly undulate; sori round to slightly oblong, inframedial; sporangia glabrous.

Etymology. The specific epithet makes reference to the type locality.

Distribution. Known only from Montañas de Celaque in Honduras at 2575 $2700 \mathrm{~m}$.

Observations. Pecluma celaquensis is similar to Polypodium martensii Mett. in its peltate rhizome scales, blade form and laminar tissue hairy, but differs in 
its thinner (2 - $3 \mathrm{~mm}$ in diameter vs. 7 - $10 \mathrm{~mm})$ rhizome, smaller $(2-3 \times 0.5$ $1.5 \mathrm{~mm}$ vs. $10-12 \times 3 \mathrm{~mm}$ ) rhizome scales and they with a crown of brown cilia (vs. without it) in the attaching point, relatively shorter $(1 / 8-1 / 6$ of the fronds size vs. $1 / 6$ - 1/4) stipe, relatively longer [(0.5-) $1-1.5 \mathrm{~mm}$ long vs. $0.8 \mathrm{~mm}$ ] stipe hairs and these commonly not glandular (vs. always glandular), scaly (vs. no scaly) rachis and it with longer [(0.5-) $1-1.5 \mathrm{~mm}$ long vs. $0.1 \mathrm{~mm}]$ and dense (vs. rare) hairs and inframedial (vs. supramedial sori and glabrous (vs. setose) sporangia. Also it is similar to Polypodium christensenii Maxon in that it has a thin rhizome and blade hairs, but differs in its smaller $(2-3 \times 0.5-1.5 \mathrm{~mm}$ vs. $6-7 \times 1-1.2 \mathrm{~mm}$ ) rhizome scales and these with a crown of brown cilia (vs. without it) in the attaching point, shorter $(45-51.5 \mathrm{~cm}$ vs. $65-120 \mathrm{~cm}$ ) fronds, a relatively shorter $(1 / 8-1 / 6$ of the fronds size vs. $1 / 4-1 / 2)$ stipe, longer $[(0.5-) 1$ - $1.5 \mathrm{~mm}$ long vs. $0.1 \mathrm{~mm}$ ] stipe hairs; entire to undulate (vs. crenulate-serrulate) blade margins and glabrous (vs. setose) sporangia (Figure 3 ).

Recent molecular evidence suggests that Polypodium s.l. is a polyphyletic assemblage, even if several segregate genera (e.g., Microgramma C. Presl, Pecluma M.G. Price, and Campyloneurum C. Presl) [13]. Schneider et al. [14] discovered that Pecluma is a genus related to Phlebodium (R. Br.) J. Sm. and also include several species of Polypodium subpetiolatum group. Although, the new species of Pecluma described here is more related to Polypodium subpetiolatum group, the species included promptly will be combined under the genus Pecluma, despite the fact that Moran [2] used the "Polypodium dulce group" (including the new species by definition).

\section{Acknowledgements}

I thank the financing and logistic collaboration in the trips of Universidad Nacional de Costa Rica (UNA), Mancomunidad de Municipios del Parque Nacional Montañas de Celaque (MAPANCE-PROCELAQUE) and Instituto Nacional de Conservación y Desarrollo Forestal, Áreas Protegidas y Vida Silvestre (ICF); to Ruth Karina Hernández Cibrian for her help with planning this trip and for helping to establish contact with several institutions in Honduras; to Misael León Carvajal and Malcolm Bryan Stufkens, for their logistical help in Parque Nacional Celaque, to Lilian Ferrufino and Paul House, curators at the Cyril Nelson Herbarium (TEFH), for their collaboration in drying, storing and distributing the specimens in Honduras; to Museo Nacional de Costa Rica (CR) for the space and equipment to review and illustrate the type material; to Karen Bermudez Barrantes, Jessica Jiménez Loría, Esteban Barrientos Martínez and Christian Herrera Martínez for their excellent drawings; the anonymous reviewers for their helpful suggestions. And to all who, in one way or another, made this work possible.

\section{References}

[1] Molina, R. (1975) Enumeración de las Plantas de Honduras. Ceiba, 19, 1-10.

[2] Moran, R.C. and Riba, R. (1995) Flora Mesoamericana. Vol. 1, Psilotaceae a 
Salviniaceae, Universidad Nacional Autónoma de México, Ciudad Universitaria, México, $470 \mathrm{p}$.

http://www.mobot.org/mobot/tropicos/meso/homep_sp.htm

[3] Nelson, C., Gamarra, R. and Fernández, J. (1996) Hondurensis Plantarum Vascularium Catalogus Pteridophyta. Fontqueria, 43, 1-139.

[4] Hernández, R. and Nelson, C. (2008) Registro de un nuevo helecho para la flora de Honduras. Revista Ciencia y Tecnología, 2, 112-115.

[5] Hazlett, D.H. (1979) A First Report on the Vegetation of Celaque. Ceiba, 23, 114128.

[6] Piątek, K., Naks, P., Heise, W., Wayda, M., Reyes, O. and Sandoval, G. (2012) Ferns and Lycophytes of Celaque National Park, Honduras. Fern Gazette, 19, 11-23.

[7] Rojas, A.F. (2012) Nuevos registros de licopodios (Lycopodiophyta) y helechos (Pteridophyta) para Honduras y el Parque Nacional Montañas de Celaque. Revista Biodiversidad Neotropical, 2, 83-92. https://doi.org/10.18636/bioneotropical.v2i2.72

[8] Lorea, F. and Riba, R. (1990) Guía para la recolección y preparación de ejemplares para herbario de Pteridofitas. Consejo Nacional de la Flora de México, México, 18 p.

[9] Thiers, B. (2016) Index Herbariorum: A Global Directory of Public Herbaria and Associated Staff. New York Botanical Garden's Virtual Herbarium. http://sweetgum.nybg.org/science/ih/

[10] Stolze, R.G. (1981) Ferns and Fern Allies of Guatemala. Part II. Polypodiaceae. Fieldiana Botany, New Series 6, 1-522.

[11] Mickel, J.T. and Smith, A.R. (2004) The Pteridophytes of Mexico. Memoirs of New York Botanical Garden, Vol. 88, New York Botanical Garden Press, New York, 1-1029.

[12] Gómez, L.D. and Arbeláez, A.L. (2009) Flora de Nicaragua, Helechos (Tomo IV). In: Stevens, W.D., Montiel, O.M. and Pool, A., Eds., Monographs in Systematic Botany from the Missouri Botanical Garden, The Missouri Botanical Garden Press, St. Louis, Vol. 116, 1-348.

[13] Smith, A.R., Kathleen, P., Schuettpelz, E., Korall, P., Schneider H. and Wolf, P.G. 2006) A Classification for Extant Ferns. Taxon, 55, 705-731. https://doi.org/10.2307/25065646

[14] Schneider, H., Smith, A.R., Cranfill, R., Hildebrand, T.J., Haufler, C.H. and Ranker, T.A. (2004) Unraveling the Phylogeny of Polygrammoid Ferns (Polypodiaceae and Grammitidaceae): Exploring Aspects of the Diversification of Epiphytic Plants. Molecular Phylogenetics and Evolution, 31, 1041-1063. 
Submit or recommend next manuscript to SCIRP and we will provide best service for you:

Accepting pre-submission inquiries through Email, Facebook, LinkedIn, Twitter, etc. A wide selection of journals (inclusive of 9 subjects, more than 200 journals)

Providing 24-hour high-quality service

User-friendly online submission system

Fair and swift peer-review system

Efficient typesetting and proofreading procedure

Display of the result of downloads and visits, as well as the number of cited articles Maximum dissemination of your research work

Submit your manuscript at: http://papersubmission.scirp.org/

Or contact ajps@scirp.org 